\title{
Investigation of The Relationship Between Lifelong Learning and Epistemological Beliefs of Associate Degree Students'
}

\author{
Gürbüz Ocak \\ Department of Science Education, Faculty of Education, Afyon Kocatepe University, \\ Afyonkarahisar, Turkey \\ ORCID: 0000-0001-8568-0364
}

\author{
Akın Karakuyu* \\ Antakya Vocational School, Hatay Mustafa Kemal University, Hatay, Turkey
} ORCID: 0000-0001-7370-5464

\begin{tabular}{|c|c|}
\hline Article history & te the relationship between lifelong \\
\hline $\begin{array}{l}\text { Received: } \\
19.03 .2021\end{array}$ & $\begin{array}{l}\text { learning and epistemological beliefs of associate degree students. In the } \\
\text { study, correlational method, which is one of the qualitative research }\end{array}$ \\
\hline $\begin{array}{l}\text { Received in revised form: } \\
11.08 .2021\end{array}$ & $\begin{array}{l}\text { methods, was employed. The population of the study consisted of } \\
\text { students studying at a vocational high school of a state university in } \\
\text { Turkey and the sample of the study consisted of } 360 \text { students selected }\end{array}$ \\
\hline $\begin{array}{l}\text { Accepted: } \\
23.08 .2021\end{array}$ & from the population through convenience sampling. In the study, the \\
\hline Key words: & the "Epistemological Beliefs Scale" adapted by Aydın, Selçuk, Çakmak \\
\hline $\begin{array}{l}\text { Lifelong learning, } \\
\text { Epistemological beliefs, } \\
\text { Associate degree students }\end{array}$ & $\begin{array}{l}\text { and Ilgan (2017) were used to collect data. Descriptive statistics, pearson } \\
\text { correlation analysis, regression analysis, hierarchical regression and two- } \\
\text { way analysis of variance were used for data analysis. As a result of the } \\
\text { study, a positive, significant and nearly medium level relationship was } \\
\text { found between lifelong learning and epistemological beliefs of associate } \\
\text { degree students. In addition, it was found that epistemological beliefs } \\
\text { predict students' lifelong learning by } 8.7 \% \text {. While there was a positive } \\
\text { and moderate level relationship between the effort dimension, which is } \\
\text { the sub dimension of epistemological beliefs, and lifelong learning, a } \\
\text { positive and weak level relationship was obtained between lifelong } \\
\text { learning and a single truth sub dimensions of the epistemological beliefs } \\
\text { scale. On the other hand, there was almost no relationship between the } \\
\text { ability sub dimension and students' lifelong learning level. In addition, } \\
\text { when the epistemological beliefs of the students and independent } \\
\text { variables (gender, class, type of education, age, department and } \\
\text { department type) were considered as common variables, no statistically } \\
\text { significant difference was found in terms of lifelong learning level of the } \\
\text { students. }\end{array}$ \\
\hline
\end{tabular}

* Correspondency: karakuyuakin@gmail.com 


\section{Introduction}

As the 21st century we live in is an age of information and technology, the structure of knowledge changes and develops day by day and is spread all over the world through communication tools. There is a density of information in the world, the information received at the beginning of the education life changes after graduation and remains inadequate. This has changed the function of schools and forced them to evolve into a position that directs schools to knowledge rather than to transfer information. As a natural consequence of this situation, learning has become an ongoing process outside the learning life instead of being limited to the formal education process. The education that individuals receive in the formal education process has necessitated informal education, which is lifelong learning, in order to keep up with the changes in the society.

The concept of lifelong learning was first introduced at a conference organized by UNESCO in Hamburg. Theoretical and practical studies on the concept were made in 1980s (Günüç, Odabaş1 and Kuzu, 2012). Since the 1990s, the European Union has adopted lifelong learning as a fundamental criterion in education systems (Pepin, 2007). In Turkey, Strategy Document has been prepared in 2009 in accordance with the strategic plan of the Ministry of Education (Şahin and Arcagök, 2014: 396)

Lifelong learning includes all activities aimed at improving individuals' knowledge, skills and competences throughout their lives (Günüç et al., 2012: 309). According to the European Commission, lifelong learning is defined as all learning activities aimed at improving knowledge, skills and abilities throughout the life of an individual in society or professionally (Dinevski and Dinevski, 2004: 228). In another definition, lifelong learning is expressed as the form of all kinds of learning activities involving individual, social, and employment related lifelong engagement in order to develop knowledge, skills, interests and competences (MEB, 2009). It can be deduced from the definitions that lifelong learning is a process that continues until the death of individuals, improving their knowledge, skills, and abilities.

As with all learning methods, lifelong learning has a specific set of objectives. Lifelong learning has three important aims as; contributing to the development of individuals by creating new opportunities in learning, helping to establish social cohesion and positively effecting economic development. In addition, lifelong learning aims to enable individuals to gain some knowledge and skills to adapt to the situation they are in for different situations in their lives (Babanli and Akçay, 2018: 89). The aims of lifelong learning are expressed on three different points as on the individuals, the society and the economy. Lifelong learning enables individuals to access to the right information, know how to use it in the right place, and learn how to learn by thinking creatively and critically (Uzunboylu and Hürsen 2011). In this study, the purpose of lifelong learning is expressed as the ability of the individual to construct information.

Saisana and Cartwright (2007) divided the building blocks of lifelong learning into four.

(1) Learning to know (reading, writing, critical thinking and general knowledge)

(2) Learning to do (acquisition of practical skills associated with the profession, such as computer training, executive training and apprenticeship training)

(3) Learning to live together (to develop values of respect and concern for others, to promote social and interpersonal skills) 
(4) Learning to exist (to develop exploratory and creative skills in an individual's physical, mental and spiritual fields through activities such as reading, using the Internet and sports and arts).

The literature on lifelong learners generally focuses on two broad dimensions. The first dimension includes information literacy skills and abilities. The second dimension includes beliefs about learning and knowledge. In addition, it is stated that epistemological beliefs are among the factors which significantly predict the characteristics of a lifelong learner (Bath and Smith, 2009). The individual's point of view to information is effective on their learning. If the individual believes that the knowledge is variable, he accepts that his own learning can also change. However, if it accepts knowledge as definite and unchangeable, it will perform learning as traditional learning activities (Kaya, 2018). The realization of lifelong learning depends on the ability of individuals to capture, adapt, and use the changing information in the conditions of the day. The ability of individuals to use information effectively in daily life is closely related to their beliefs and epistemological beliefs which means knowledge science.

Epistemological belief is the belief of individuals about what knowledge is and how they can realize learning (Deryakulu, 2004: 233). In another definition, epistemological beliefs are defined as socially shared intuitions about the nature of learning and knowledge based on the limits, certainty and criteria of knowing (Jehng, Johnson and Anderson, 1993: 24). There are three basic questions in the field of epistemology. These questions are as: "What are the limits of human knowledge?", "What are the sources of human knowledge?" and "What is the nature of human knowledge?" (Muis, Bendixen and Haerle, 2006: 6).

Epistemological beliefs have a two-structure form viz. the nature of knowledge and the nature of the knowing; and consist of four dimensions as the absoluteness of knowledge, the development of scientific knowledge, the source of information and justification of scientific knowledge (Kampa, Neumann, Heitmann and Kremer, 2016: 82). The dimensions of the source of this information, the development and justification of knowledge are necessary for individuals to acquire life-long learning.

It was determined that epistemological beliefs have a decisive effect on variables such as processing, interpreting, comprehension of the new knowledge, higher order thinking, problem solving skills, and time spent for learning (Brownlee, Purdie and Boulton-Lewis, 2001: 11). These variables have the same characteristics as learning to learn, which is one of the competencies of lifelong learning.

When look at the studies on the subject; Kaya (2018) in the study, where teachers examined the relationship between epistemological beliefs and lifelong learning, he found a positive, moderate level and significant relationship between epistemological beliefs and lifelong learning competencies. Arslan (2017) in his doctoral study, examined the relationship between epistemological beliefs and lifelong learning of physicians, medical students and faculty members' she found a positive, moderate level and significant relationship between epistemological beliefs and lifelong learning. Liang and Tsai (2010) revealed consistency between university students' epistemological beliefs and lifelong learning. In the literature, no studies investigating the relationship between associate degree students' epistemological beliefs and lifelong learning have been found. Bell (2006) stated that one of the predictors that will affect the lifelong learning performance of individuals may be self-regulated learning and the other may be epistemological beliefs. 
Universities have a distinct role in lifelong learning. Dinevski and Dinevski (2004: 231) expressed the role of universities in this regard as e-learning, virtual university, and internetbased education, which provides the opportunity for professional development and improves the dissemination of knowledge. On the other hand, there is no study examining the relationship between the epistemological beliefs of associate degree students and their lifelong learning in the literature. The study is thought to fill this gap in the literature.

\section{Aim of the Study}

The aim of this study is to investigate whether there is a significant relationship between lifelong learning and epistemological beliefs of associate degree students. Depending on this general purpose, it is aimed to examine whether this relationship varies depending on the variables of gender, age, department, department type, type of education and grade.

\section{Problem Statement}

Is there a relationship between lifelong learning and epistemological beliefs of associate degree students?

\section{Sub-Problems}

(1) What is the lifelong learning level of associate degree students?

(2) What is the level of epistemological belief and epistemological belief sub-dimensions of associate degree students?

(3) Is there a statistically significant relationship between lifelong learning with epistemological beliefs and epistemological beliefs sub-dimensions of associate degree students?

(4) Are the epistemological beliefs a predictor of lifelong learning of associate degree students?

(5) Are the sub-dimensions of epistemological beliefs a predictor of lifelong learning of associate degree students?

(6) Is there a significant difference in lifelong learning levels of associate degree students depending on the common effect of:

- gender and epistemological belief levels?

- grade and epistemological belief levels?

- learning type and epistemological belief levels?

- age and epistemological belief levels?

- department and epistemological belief levels?

- program type and epistemological belief levels?

\section{Methodology}

\section{Research Model}

In the study, correlational survey model was adopted from survey models. General screening models are conducted on the whole population or the sample to be taken from it in order to make a general judgment about the population (Karasar, 2004; 77). In this study, correlational model was used since in the study the estimation and interpretation of the other variable was conducted by knowing the situation in one variable through survey model. The correlational model provides a better understanding and estimation of the phenomenon by investigating the relationship between variables (Büyüköztürk et al., 2011: 22). In addition, the 
predictive role of students' epistemological beliefs on their lifelong learning was determined in the study. According to Cohen, Cohen, West, and Alken (2003) the descriptive correlational method is used to determine the degree of change between two or more variables.

\section{Sample}

The population of the study consisted of university students studying in a vocational high scholl of a state university in Hatay city, Turkey. The sample of the study consists of 360 associate degree students who were selected by convenience sampling from the universe and participated in the study voluntarily. In convenience sampling, the researcher determines a sufficient number of items from the universe as a sample. For this reason, sampling is also called random or accidental sampling (Singleton \& Straits, 2010). This sampling is low-cost and does not require much time (Fricker, 2006). It is used when participants who are easily accessible and willing to participate in the research are included in the sample (Johnson \& Chiristensen, 2014). In this study, volunteerism was taken into account and the participant who were willing to participate in the study were included.

Table 1. Demographic information

\begin{tabular}{lll}
\hline Demographic information & f & $\%$ \\
\hline Gender & 242 & 67.2 \\
Male & 118 & 32.8 \\
Female & & 55.8 \\
\hline Grade & 201 & 44.2 \\
$1^{\text {st }}$ Grade & 159 & 68.6 \\
$2^{\text {nd }}$ Grade & & 31.4 \\
\hline Education Type & 246 & 10.6 \\
Day time education & 114 & 28.3 \\
Evening time education & & 24.4 \\
\hline Age & 38 & 15.0 \\
18 & 102 & 21.7 \\
19 & 88 & 10.0 \\
20 & 54 & 16.4 \\
21 & 78 & 35.6 \\
$22+$ & & 6.7 \\
\hline Department & 36 & 23.6 \\
Child Development & 59 & 7.8 \\
Lrivate Security & 128 & 61.9 \\
Conistics & 24 & 38.1 \\
Computer Technology & 85 & 28 \\
Electronics Technology & & 223 \\
\hline Program Type & 137 & \\
Technical Programs & & \\
\hline
\end{tabular}

According to the Table $1 ; 32.8 \%$ of the students were female and $67.2 \%$ were male. $55.8 \%$ of the students were in the 1 st grade, $44.2 \%$ were in the 2 nd grade, $68.6 \%$ were at daytime education and $31.4 \%$ were at evening education. $10.6 \%$ were 18 years old, $28 \% 3$ of them were 19 years old, $24.4 \%$ were 20 years old, $15.0 \%$ were 21 years old, $21.7 \%$ were 22 years old and over. $10 \%$ of the students were at child development, $16.4 \%$ were at private security, $35.6 \%$ were at logistics, $6.7 \%$ were at construction, $23.6 \%$ were at computer, $7.8 \%$ were at electrical department. $61.9 \%$ of them were studying at social and $38.1 \%$ were studying at technical programs. 


\section{Data Collection Tools}

Data of the study were collected using lifelong learning and epistemological beliefs scales.

Lifelong Learning Scale: It is originally developed by Wielkiewicz and Meuwissen in 2014 in English. The scale is a five-point Likert-type instrument consisting of 16 items and it is a one-dimensional scale. The scale was adapted to Turkish by Engin, Kör and Erbay (2017). The scale was applied to 727 university students for the adaptation study, and exploratory and confirmatory factor analyzes were performed. As a result of factor analysis, one item was removed from the scale and the final version of the scale was obtained as 15 items and one dimension. The Cronbach Alpha reliability coefficient of the Turkish form of the scale was found as 0.93 . The cronbach's alpha coefficient for the sample was found as 0.858 .

Epistemological Beliefs Scale: It is originally developed by Schommer and adopted to Turkish in 2002 by Deryakulu and Büyüköztürk. The scale was adopted again in 2017 by Aydın, Selçuk, Çakmak and İlğan which was used in this study. The validity and reliability of this version of the scale was conducted on 1242 teacher candidates studying at Science, Social Studies, Turkish and Classroom Teaching departments. The scale consists of 23 items and it is a three-dimensional scale. The alfa internal consistency coefficients were found as 0.88 for effort, 0.88 for ability and 0.85 for single truth subdimensions. As a result of all analyzes, it was concluded that the scale was valid and reliable in three-dimensional structure. For the sample in this study, the Cronbach alpha coefficient was calculated as 0.865 .

\section{Data Analysis}

In order to test whether the data showed normal distribution, skewness and kurtosis analysis, Pearson correlation analysis for the relationship between the variables, regression to test the prediction power, and two-way Anova analyses for the relationship between the common effect of the independent variables on the dependent variable were conducted. In addition, hierarchical regression was used to prediction power the lifelong learning of the sub dimensions of the epistemological beliefs scale.

\section{Research Process}

The research was carried out in the autumn semester of the 2019-2020 academic year. The necessary permissions were obtained from the institution where the research was conducted and the participants were given the necessary information about the research. Volunteering was taken into account in the participation of the participants in the research. Scale forms were distributed duplicated by photocopy to the participants. The application process was carried out by the researchers. In the data collection process, researchers answered the questions asked by the students about the scale items. After the scales were applied to the students, the scale forms were checked, and the incomplete forms were excluded.

\section{Findings}

The findings of the study are presented as follows in accordance with the sub-problems of the study.

Descriptive statistical results of the students' scores obtained from lifelong learning scale are given in table 2.

Table 2. Descriptive statistics results of lifelong learning scale 


\begin{tabular}{llllll}
\hline & $\mathrm{N}$ & Min. & Max. & Mean & St. Error \\
\hline Lifelong Learning & 360 & 25 & 75 & 55.59 & 9.38 \\
\hline
\end{tabular}

According to the data in Table 2, the average score obtained from lifelong learning scale was found as 55.59 and the standard deviation was as 9.38. The scores that can be obtained from lifelong learning scale are between 15-75. 15-34 points were considered as low, 35-54 points were considered as medium, and 55-75 points were considered as high. According to the obtained mean score, lifelong learning level of associate degree students was found as high.

The descriptive statistics of the scores obtained from the epistemological beliefs scale and subdimensions are given in Table 3

Table 3. Descriptive statistical results of epistemological beliefs and sub-dimensions

\begin{tabular}{lccccc}
\hline & $\mathrm{N}$ & Min. & Max. & Mean & St. Error \\
\hline Epistemological Beliefs & 360 & 23 & 115 & 78.68 & 13.58 \\
Effort sub-dimension & 360 & 10 & 50 & 40.35 & 6.46 \\
Ability sub-dimension & 360 & 8 & 40 & 22.39 & 7.60 \\
Single Truth sub-dimension & 360 & 5 & 25 & 15.94 & 4.90 \\
\hline
\end{tabular}

According to the descriptive statistics in Table 3, the mean score of the students on the epistemological beliefs scale was 78.68 and the standard deviation was 13.58 . The mean score was found as 40.35 and the standard error was found as 6.46 for effort sub-dimension. Mean score was found as 22.39 and standard deviation was as 7.60 for the ability sub-dimension. Mean score was found as 15.49 and standard deviation was as 4.90 for the ability subdimension. According to the obtained mean score, epistemological beliefs level of associate degree students was found as middle. Effort sub-dimension is at a high level, ability and single truth sub-dimensions are at a middle level.

Pearson correlation analysis was performed to determine the relationship between lifelong learning, which is the dependent variable of the study, and epistemological beliefs, which are independent variables, and the results are given in Table 4.

Table 4. The Relationship between lifelong learning and epistemological beliefs and subdimensions

\begin{tabular}{llll}
\hline & Lifelong & Learning & \\
\hline & $\mathrm{N}$ & $\mathrm{r}$ & $\mathrm{p}$ \\
Epistemological Beliefs & 360 & .295 & $.00^{* *}$ \\
Effort sub-dimension & 360 & .385 & $.00^{* *}$ \\
Single Truth sub-dimension & 360 & .159 & $.00^{* *}$ \\
Ability sub-dimension & 360 & .096 & .00 \\
\hline
\end{tabular}

According to the results of the analysis in Table 4, there was a significant positive and medium 
level correlation at the level of .01 between the lifelong learning and epistemological beliefs of the associate students. A r value of .295 indicates that the reported relationship between lifelong learning and epistemological beliefs is $29.5 \%$. In addition, significant positive relationship was obtained between the epistemological beliefs sub-dimensions and the total scores of lifelong learning ( $\mathrm{r}: 0.385 ; \mathrm{p}<0.01)$, with a single true dimension ( $\mathrm{r}: 0.159 ; \mathrm{p}<0.01)$. On the other hand, it was found that the relationship between the ability sub-dimension and lifelong learning was negligible.

Regression analysis was conducted to determine whether the participants' lifelong learning and epistemological beliefs were predictors of each other, and the results are given in Table 5

Table 5. Results of regression analysis between lifelong learning and epistemological beliefs of students

\begin{tabular}{lllllll}
\hline & $\beta$ & $\mathrm{t}$ & $\mathrm{p}$ & $\mathrm{R}^{2}$ & $\mathrm{~F}$ & $\mathrm{p}$ \\
\hline Regression Coefficient & 39.818 & 14.287 & .00 & & & \\
Epistemological Beliefs & .204 & 5.835 & .00 & .087 & 34.046 & $.00^{* *}$ \\
\hline
\end{tabular}

As can be seen in Table 5, when the independent variable epistemological beliefs were included in the analysis, epistemological beliefs have a statistically significant contribution in predicting the lifelong learning of associate degree students. $\mathrm{A} \mathrm{R}^{2}$ value of .087 indicates that $8.7 \%$ of students' lifelong learning is predicted by the epistemological beliefs variable.

Hierarchical regression analysis was performed to determine to what extent epistemological beliefs sub-dimensions predict the lifelong learning level of associate degree students and the results are presented in Table 6

Table 6. Hierarchical regression analysis results

\begin{tabular}{lllll}
\hline Variables & & B & St. Error & $\beta$ \\
\hline \multirow{2}{*}{ Model 1 } & Effort & .560 & .071 & $.385^{*}$ \\
Model 2 & Effort & .536 & .72 & $.369^{*}$ \\
& Single Truth & .184 & .094 & $.096^{*}$ \\
& & 31.271 & 3.057 & \\
\hline
\end{tabular}

B: Regression coefficient, $\beta$ : standard regression coefficient, F: 33.382, p: 0.00

The $\mathrm{R}^{2}$ value of .149 for the effort dimension of the epistemological beliefs scale indicate that the change of $14.9 \%$ in students' lifelong learning was caused by this sub-dimension. In addition, $\mathrm{R}^{2}$ value of .025 for single truth sb-dimension indicate that $2.5 \%$ of the change in students' lifelong learning was caused by this sub-dimension.

In this study, two-way ANOVA was used to determine whether the demographic characteristics and epistemological belief levels had common effect on lifelong learning of associate degree students and the results were given in Table 7. 
Table 7. Two-Way Anova results

\begin{tabular}{lcccc}
\hline Variables & sd & Mean Square & F & p \\
\hline Epistemological Belief Level*Gender & 2 & 165.547 & 2.047 & .131 \\
Epistemological Belief Level*Grade & 2 & 28.609 & .350 & .705 \\
Epistemological Belief Level*Education Type & 2 & 49.357 & .604 & .547 \\
Epistemological Belief Level*Age & 7 & 61.445 & .754 & .626 \\
Epistemological Belief Level*Department & 9 & 114.364 & 1.412 & .181 \\
Epistemological Belief Level*Program Type & 2 & 28.120 & .345 & .709 \\
\hline
\end{tabular}

According to the two-way ANOVA results in Table 7, it was found that gender and epistemological belief levels $(\mathrm{F}=2.047, \mathrm{p}>.05)$, grade and epistemological belief levels $(\mathrm{F}=$ $.350, \mathrm{p}>.05)$, type of education and epistemological belief levels ( $\mathrm{F}=.604, \mathrm{p}>.05)$, age and epistemological belief levels $(\mathrm{F}=.754, \mathrm{p}>.05)$, department and epistemological belief levels $(\mathrm{F}=1.412, \mathrm{p}>.05)$, and program type and epistemological belief levels $(\mathrm{F}=.345, \mathrm{p}>.05)$ did not have common effect on lifelong learning of students.

\section{Conclusion and Discussion}

In this study it was aimed to determine the direction, level of the relationship between lifelong learning and epistemological beliefs of associate degree students and to determine the predictive power of these variables.

With the changing conditions of the day and the changing structure of knowledge, learning continues not only formally but also extensively when school life ends. Lifelong learning, as the name suggests, is a concept that expresses the continuation of the learning activity throughout the life of the individual. Individuals' beliefs in knowledge play an important role in the realization of learning. Epistemological beliefs, which mean knowledge science and express our beliefs about knowledge, is one of the factors that can affect lifelong learning. According to Pintrich (2002), individual's awareness of how knowledge is formed, and belief in changes in knowledge and learning are the cornerstones of lifelong learning. Paulsen and Felman (2007) concluded that students with complex epistemological beliefs have a higher probability of lifelong learning by participating in self-regulated learning strategies than their peers.

In the study, a statistically significant, positive, and nearly medium level relationship was found between associate degree students' lifelong learning and epistemological beliefs. In addition, it was found that students' epistemological beliefs predicted the lifelong learning by $8.7 \%$. While there was a positive relationship between the effort and single truth, which are the subdimensions of epistemological beliefs, and the lifelong learning level of students, nearly no almost statistically significant relationship was found between ability sub-dimension and the lifelong learning level of students. This may be due to the fact that epistemological belief expresses our perspective on knowledge that guides learning. In some studies in literature, there are similar results to the results of this study between the lifelong learning of participants and their epistemological beliefs (Arslan, 2017; Kaya, 2018).

In the study, the average score of the undergraduate students obtained from life lon learning 
scale was found as 55, 59. According to this value, it can be said that lifelong learning levels of the students are at high level. This finding shows similarity with the various studies in the literature (Karakuş 2013; Ayaz, 2016; Demiralp and Kazu, 2017; Karaoğlan Y1lmaz and Binay Eyüboğlu, 2018; Babanlı and Akçay, 2018). The high level of lifelong learning found in the study is very important for associate degree students, who have significant role in business life, in terms of following, adapting, and applying the innovations in business life. There are also some studies in which the lifelong learning of the participants was found at moderate level (Coşkun Diker, 2009; Tunca, Şahin and Aydın 2015; Duymuş and Sulak 2018).

No significant difference was obtained in lifelong learning level of the students when students' gender and epistemological belief levels were considered as common variables. Lifelong learning is more about individuals' viewpoints, experiences and readiness. At this point, we can say that gender was not a decisive variable. In the literature, there were some studies with similar findings (Jenkins, 2004; Ayra et al., 2016; Özçiftçi and Çakır, 201; Demiralp and Kazu, 2017; Karaman and Aydoğmuş, 2018) and some studies which were paralle to the findings of the current study (Şahin and Arcagök, 2014; Duymuş and Sulak, 2018; Kabatas and Karaoglan Yilmaz, 2018; Karaoglan Yilmaz and Binay Eyuboglu, 2018; Babanli and Akcay, 2018).

This may be due to the fact that there is not enough time to create a meaningful difference between the first- and second-year students in vocational schools since the education lasts for two years. Demiralp and Kazu (2017) found no significant difference in lifelong learning among first and fourth grade students. There are some studies with significant differences in the literature (Karakuş, 2013). In this study, the results were in favor of higher grades. Karaman and Aydoğmuş (2018) found a significant difference in favor of 2nd grade students according to the sub-dimensions of deprivation to regulate learning and motivation of lifelong learning. In the study, when class level and epistemological beliefs levels were considered as common variables, no relationship was found in lifelong learning. This may be due to the fact that there is not enough time to create a meaningful difference between the first- and second-year students in vocational schools since the education lasts for two years. In addition, no relationship was found between lifelong learning according to the status of primary and secondary education, and the types of teaching and epistemological beliefs as a common variable.

In this study, no significant difference was found in lifelong learning level of the students when students' gender and epistemological belief levels were considered as common variables. The reason for this may be the fact that the students in this sample group were quite close to each other as in 18-20 age range. Karaoğlan Yılmaz and Binay Eyuboğlu (2018) reported that when 21-30 age group was compared to 41-50 age group according to the sub-dimensions of teachers' LLL attitudes in terms of technology acceptances and digital indigenousness, a statistically significant difference was obtained in favor of the 21-30 age group. In the study of Babanl1 and Akçay (2018), those in the age group between 26 and 35 differed significantly in the subdimension of Learning Competence from Digital Technology compared to other groups.

According to the results of two-way ANOVA, there was no significant difference in LLL level of the students when the program type and epistemolojical beliefs were taken as common variables. As Scheuch, Shouping, and Gaston (2009) note, this result may be due to insufficient basic research and learning skills required in other disciplines, although the students have some knowledge and skills related to the field they study. Associate students in the study group have to gain knowledge and skills in a rapid fashion in order to be able to adjust themselves to these novel changes in social and technical fields. For this reason, there may be no significant difference in LLL when students' program types and epistemological beliefs are considered as 
common variables.

No significant difference was found in lifelong learning level of the students when students' departments and epistemological belief levels were considered as common variables. Lifelong learning is shaped according to the individual's perspective of life, which affects all the departments that students study at. Arsal, 2011; Karakuş, 2013; Duymuş and Sulak, in their studies in 2018, did not find any difference between department variable and lifelong learning. In their study with university students, Bimrose et al. (2003) stated that students focused more on career development rather than personality development The fact that associate students who are worried about finding a job when they graduate are more oriented towards career development supports this result of the study.

As a result, in the age of technology we live in, the most produced and shared item is information. For this reason, learning is not limited to formal education only in a certain period of life but has to continue throughout life. As in all learning, knowledge has an important place in lifelong learning. Approaches towards knowledge for the acquisition of knowledge, questioning of knowledge, production and sharing of knowledge, which are effective in the realization of learning, epistemological beliefs, are confronted as an important factor in the realization of lifelong learning.

Suggestions in this context can be enlisted as follows:

- Steps can be taken to raise awareness about epistemological beliefs, which express our beliefs against knowledge, which will enable us to catch up with today's changes, which are the basis of lifelong learning and other learning.

- Causal studies examining the relationship between epistemological beliefs and lifelong learning can be conducted by considering the sub-competencies of lifelong learning.

- The studies examining the relationship between epistemological beliefs and lifelong learning are limited. Research can be conducted on different student groups such as secondary school, high school and university students.

- It is seen that the studies on lifelong learning and epistemological beliefs were mostly conducted with students, pre-service teachers, and teachers. However, these two concepts are closely related to those who are not in the formal education process as well as those who are in the formal education process. For this reason, it is recommended to conduct research with sample groups of different occupational groups and adults.

\section{References}

Arsal, Z. (2011). Lifelong learning tendencies of the prospective teachers in the Bologna process in Turkey. ATTE Annual Conference 2011: Teachers' Life-Cycle from Initial Teacher Education to Experienced Professional, Latvia University, Riga 496-509.

Arslan, Ș.F. (2017). Hekimlerin, tıp fakültesi ögrencilerinin ve ögretim üyelerinin epistemolojik inançlarl ve yaşam boyu öğrenme eğilimlerinin incelenmesi [Investigation of physicians', medical students' and faculty members' epistemological beliefs and lifelong learning tendency], Unpublished doctoral thesis, Marmara University.

Ayaz, C. (2016). Öğretmenlerin yaşam boyu öğrenme ĕgilimlerinin bazı değiş̧kenler açısından incelenmesi. [The analysis of lifelong learning tendencies of teachers in terms of some veriables], Unpublished master's thesis, Bartın University.

Aydın, S., Selçuk, G., Çakmak, A. \& İlğan, A. (2017) Epistemolojik inançlar ölçeği Türkçe formunun geçerlik ve güvenirlik çalışması [Validity and reliability study of turkish form 
of epistemological beliefs scale], Bartın University Journal of Faculty of Education, 6(3), $1166-1188$.

Ayra, M., Kösterelioğlu, İ. \& Çelen, Ü. (2016). Öğretmenlerin yaşam boyu öğrenme eğilimlerinin çeşitli değişkenler açısından incelenmesi [Identifying the lifelong learning tendencies of the teachers in terms of different variables], Hitit Journal of Social Sciences, 9(1), 497-516.

Babanl1, N. \& Akçay, R.C. (2018). Yetişkin eğitimindeki kursiyerlerin yaşam boyu öğrenme yeterlikleri [Lifelong learning competencies of trainees in adult education], Inonu University Journal of the Graduate School of Education, 5(9), 87 - 104.

Bath, D. M. \& Smith, C. D. (2009). The relationship between epistemological beliefs and the propensity for lifelong learning. Studies in Continuing Education, 31(2), 173-189.

Bell , P.D. (2006). Can factors related to self-regulated learning and epistemological beliefs predict learning achievement in undergraduate asynchronous web-based courses? Unpublished doctoral dissertation , North Carolina State University

Brownlee, J., Purdie, N. \& Boluton-Lewis, G. (2001). Changing epistemological beliefs in preservice teacher education students. Teaching in Higher Education, 6(2), 247-268.

Büyüköztürk, Ş., Kılıç Çakmak, E., Akgün, Ö.E., Karadeniz, Ş. \& Demirel, F. (2011), Bilimsel araştırma yöntemleri, [Scientific research methods], Pegem Academy Publishing, 10.Bask1.

Cohen, J., Cohen, P., West, S. G., \& Alken, L. S. (2003). Applied multiple regression/correlation analysis for the behavioural sciences (3rd ed.). Mahwah, New Jersey: Lawrence Erlbaum Associates, Inc.

Coşkun Diker, Y. (2009) Üniversite öğrencilerinin yaşam boyu öğrenme becerilerinin bazı değişkenler açısından incelenmesi.[Investigation of life long learning tendency of undergraduate students? in terms of some variables], Unpublished doctoral dissertation, Hacettepe University.

Demiralp, D. \& Kazu, H. (2017) Öğretmen adaylarinin etkili yaşam boyu öğrenme düzeylerinin çeşitli değişkenler açisindan karşilaştirilmasi [Comparison of effective lifelong learning levels of pre-service teachers in terms of various variables] Inonu University Journal of the Faculty of Education (INUJFE), 18( 3), 71-85

Deryakulu, D. (2004). Üniversite öğrencilerinin öğrenme ve ders çalışma stratejileri ile epistemolojik inançları arasındaki ilişki [The Relationships between university students; learning and study strategies and their epistemological beliefs]. Educational Administration: Theory and Practice 10(38), 230-249.

Dinevski, D. \& Dinevski, I. V. (2004). The Concepts of university lifelong learning provision in Europe. Transition Studies Review, 11(3), 227-235

Duymuş, Y. \& Sulak, S.(2018). Öğretmen adaylarının yaşam boyu öğrenme eğilimleri üzerinde lisans eğitimi, cinsiyet ve bölümün etkisi [The Effect of undergraduate education, gender and department on prospective teachers' lifelong learning dispositions], The Journal of Limitless Education and Research, 3(2), 58 - 74

Engin, M., Kör, H. \& Erbay, H. (2017) Yaşam boyu öğrenme ölçeği türkçe uyarlama çalışması [Turkish adaptation study of lifelong learning scale], Kastamonu Education Journal, 25(4), 1561-1572.

Fricker, J. D. R., (2006). Sampling methods for web and e-mail surveys. Naval Postgraduate School.

Günüç S., Odabaşı F. H. \& Kuzu A.(2012). Yaşam boyu öğrenmeyi etkileyen faktörler [Factors affecting lifelong learning], Gaziantep University Journal of Social Sciences, 11(2), 309 $-325$

Jenkins, A. (2004). Women, Lifelong Learning and Employment Report. Centre For The Economics of Education. U.K. London School of Economics and Political Science, 
Retrieved from http://eprints.Ise.ac.uk/19467/1/Women,_Lifelong_Learning_and_Employment.pdf (Access: 03.12.2019).

Jehng, J-C., Johnson, S-D. \& Anderson, R.C. (1993) Schooling and Students' Epistemological Beliefs about Learning, Contemporary Educational Psychology, 18 (1), 23-35.

Johnson, B. \& Christensen, L. (2014). Nitel, nicel ve karma yöntem yaklaşımları: Ĕ̈itim araştırmaları (S. B. Demir, Çev. Ed.). [Qualitative, quantitative and mixed method approaches: Educational research (S. B. Demir, Trans. Ed.).] Trainer Book Publications.

Kabataş, S. \& Karaoğlan Yılmaz, F.G. (2018). Öğretmenlerin yaşam boyu öğrenme tutumlarının eğitim teknolojileri standartlarına yönelik öz-yeterlikleri açısından değerlendirilmesi [Evaluation of teachers' lifelong learning attitudes in terms of selfefficacy towards the standards of educational technology], Bartın University Journal of Faculty of Education, 7(2), 588-607

Kampa, N., Neumann, I., Heitmann, P. \& Kremer, K. (2016). Epistemological beliefs in science -aperson-centered approach to investigate high school students' profiles. Contemporary Educational Psychology, 46, 81-93.

Karaman, D. \& Aydoğmuş, U.(2018) Üniversite öğrencilerinin yaşam boyu öğrenme eğilimleri [Living length learning trends of university students,] Nevşehir Hacı Bektaş University Journal of Social Science Institute, 8(1), 23 - 44 Retrieved from, http://dergipark.gov.tr/download/article-file/497729 (Access: 10.12.2019).

Karakuş, C. (2013). Meslek yüksek okulu öğrencilerinin yaşam boyu öğrenme yeterlikleri. [Lifelong learning competences of vocational school students] Journal of Research in Education and Teaching 2 (3), 26-35.

Karaoğlan Yılmaz, F.G \& Binay Eyuboğlu, F.A. (2018) Öğretmenlerin yaşam boyu öğrenme tutumları, dijital yerli olma durumları ve teknoloji kabulü arasındaki ilişkinin birbirleri ile ve çeşitli değişkenler açısından incelenmesi [Lifelong learning competences of vocational school students,] International Journal of Education Science and Technology, 4 (1), 1-17

Karasar, N. (2004). Bilimsel araştırma yöntemi, [Scientific Research Method] Nobel Publications.

Kaya, K. (2018). Öğretmenlerin bilimsel epistemolojik inançlari ile yaşam boyu ögrenme yeterlikleri arasındaki ilişki, [Relationship between teachers' scientific epistemological beliefs and lifelong learning competencies] Unpublished master's dissertation, Van Yüzüncü Y1l University.

Liang, J. C. \& Tsai, C. C. (2010). Relational analysis of college science-major students' epistemological beliefs toward science and conceptions of learning science. International Journal of Science Education, 32(17), 2273-2289.

MEB. (2009). Türkiye hayat boyu öğrenme strateji belgesi-yüksek planlama kurulu. [Turkey lifelong learning strategy document-high planning board], Republic of Turkey Ministry of National Education.

Muis, K. R., Bendixen, L. D. \& Haerle, F. C. (2006). Domain-Generality and domain specificity in personal epistemology research: philosophical and empirical reflections in the development of a theoretical framework. Educational Psychology Review, 18(1), 3-54.

Özçiftçi, M. \& Çakır, R. (2015). Öğretmenlerin yaşam boyu öğrenme eğilimleri ve eğitim teknolojisi standartları özyeterliklerinin incelenmesi [Teachers' lifelong learning trends and self-efficiencies about the educational technology standards.] Educational Technology Theory and Practic, 5(1), $1-19$.

Paulsen, M.B., \& Feldman, K.A.(2007). The conditional and interaction effects of epistemological beliefs on the self-regulated learning of college students: Cognitive and behavioral strategies, Research in Higher Education, 48 (3), 353 - 401. 
Pepin, L. (2007). The History of EU cooperation in the field of education and training: how lifelong learning became a strategic objective. European Journal of Education, 42(1), 121-132.

Pintrich, P. R. (2002). Future challenges and directions for theory and research on personal epistemology. In: Hofer, B. K., and Pintrich, P. R. (eds.), Personal Epistemology: The Psychology of Beliefs about Knowledge and Knowing, Lawrence Erlbaum, Maswah, NJ, pp. 389-414.

Saisana, M. \& Cartwright, F. (2007). Measuring lifelong learning and its impact on happinessthe canadian paradigm, International Conference on Policies for Happiness, Siena 1417 June 2007

Scheuch, K., Shouping, H. \& Gaston, G.J. (2009) The influences of faculty on undergraduate student participation in research and creative activities. Innovative Higher Education, 34(3), 173-183.

Singleton, R. \& Straits, B. (2010). Approaches to social research, 5th ed., Oxford University Press, ISBN: 978-0-19-537298-4

Şahin, Ç. \& Arcagök, S. (2014). Öğretmenlerin yaşam boyu öğrenme yeterlikleri düzeyinin çeşitli değişkenler açısından incelenmesi [Examination of the teachers' lifelong learning competences levels in terms of some variables]. Adiyaman University Journal of Social Sciences, 7( 16), $394-417$.

Tunca, N., Alın-Şahin, S. \& Aydın, Ö. (2015). Öğretmen adaylarının yaşam boyu öğrenme eğilimleri [Life-long learning tendencies of pre-service teachers], Mersin University Journal of the Faculty of Education, 11 (2), 432-446.

Uzunboylu, H. \& Hürsen, Ç. (2011). Lifelong learning competence scale: the study of validty and reliability, Hacettepe University Journal of the Faculty of Education, 2011(41), 449-460. 